\title{
Pembentukan Indeks Pengukuran Kualitas Komunikasi: Strategi dalam Menangani Perilaku Menyimpang Remaja pada Siswa SMP
}

\author{
Sugito \\ Sekolah Tinggi Agama Islam Rokan \\ Jl. Lintas Riau-Sumut Km. 6 Rokan Hilir-Riau, Indonesia \\ Koresponden: Sugito@gmail.co.id
}

\begin{abstract}
ABSTRAK
Penelitian ini bertujuan untuk mengetahui dan menghasilkan indeks pengukuran kualitas komunikasi keluarga sebagai strategi menangani penyimpangan perilaku di kalangan remaja pada siswa SMP Hikmatul Fadhillah Medan. Penelitian ini menggunakan pendekatan kuantitatif metode korelasional. Populasi diambil dari remaja berumur 13-16 yang akan dipilih menjadi responden penelitian. Hasil penelitian teridentifikasi keterbukaan (openness) masih perlu ditingkatkan. Sebagian besar anak kadang-kadang menghindar, jika orangtua sedang sibuk. Hal ini menunjukkan sikap empati (empathy) yang perlu lebih ditanamkan. Dukungan (supportivenness) orangtua terhadap anak sudah berjalan dan dapat terlihat dari hasil jawaban kuesioner yang lebih banyak orangtua memberi izin akan hal-hal yang berprestasi. Rasa positif (positiveness) sangat erat dengan dukungan sehingga perlu kepada orangtua untuk berpartisipasi pada kegiatan yang dilakukan remaja. Saling menghargai dan menghormati baik terhadap yang lebih muda maupun yang lebih tua serta saling bercerita merupakan Kesetaraan/kesamaan (equality) yang terjadi dalam komunikasi keluarga. Pada siswa SMP Hikmatul Fadhillah Medan terdapat perilaku menyimpang remaja, namun dalam jumlah dan persentase yang kecil. Hasil penelitian ini juga menunjukkan pengaruh terhadap perilaku ini memperkuat teori S-O-R (Stimulus Organisme Respon) yang mengemukakan bahwa tingkah laku sosial dapat dimengerti melalui suatu analisis dari stimulus yang diberikan dan mempengaruhi reaksi yang spesifik dan didukung oleh hukum maupun penghargaan sesuai dengan reaksi.
\end{abstract}

Kata Kunci: Strategi, Keterbukaan, Empati, Dukungan, Kesetaraan

\section{ABSTRACT}

This study aims to find out and produce an index measuring the quality of family communication as a strategy to deal with behavioral deviations among adolescents in Hikmatul Fadhillah Middle School students in Medan. This study uses a quantitative approach to the correlational method. The population is taken from adolescents aged 13-16 who will be chosen as research respondents. The research results identified based on openness still need to be improved. Most children sometimes avoid when parents are busy, this shows an empathy (empathy) attitude that needs to be instilled. People's support for the child is already running can be seen from the results of the questionnaire answers that are more like parents giving permission for things that excel. Positive feelings (positiveness) are very close to support so it is necessary for parents to participate in activities carried out by adolescents. Mutual respect and respect for both younger and older and telling each other is equality that occurs in family communication.

Keywords: Strategy, Openness, Empathy, Support, Equality

\section{Pendahuluan}

Indeks kejahatan yang dilakukan di Indonesia sepanjang tahun 2012 sudah teramat sangat mengkhawatirkan, yaitu setiap 91 detik terjadi satu kejahatan, sebagaimana yang disampaikan oleh Wakil Kepala Badan Reserse Kriminal Polri Inspektur Jenderal Polisi Saud Usman dalam acara refleksi akhir tahun dan hak asasi manusia di kantor Kementrian Hukum dan HAM, di Jakarta (26 Desember 2012), bahwa "hingga November 
2012 angka kejahatan di Indonesia mencapai 316.500 kasus. Resiko penduduk yang mengalami kejahatan sekitar 136 orang tahun ini. Dengan demikian setiap 1 menit 31 detik terjadi satu kejahatan" (Kompas.co.id, 2012.

Di kota Medan masalah perilaku menyimpang remaja juga merupakan masalah yang kompleks. Sejalan dengan arus globalisasi dan teknologi yang semakin berkembang, arus informasi yang semakin mudah diakses serta gaya hidup yang modernisasi, disamping memudahkan dalam mengetahui berbagai informasi di berbagai media, di sisi lain juga membawa suatu dampak negatif yang cukup meluas diberbagai lapisan masyarakat terutama bagi kalangan remaja sehingga banyak yang terjebak dengan perilaku-perilaku negatif yang mennyimpang.

Contoh perilaku menyimpang di kota Medan diantaranya adalah tawuran antar pelajar, penjambretan, pencurian sepeda motor, kegiatan geng kereta atau geng motor, tindakan asusila seperti pencabulan dan pemerkosaan serta pemakaian obat-obatan terlarang, baik narkotika maupun psikotropika. Sebagaimana yang dinyatakan Kasat Reskrim Polresta Medan, "dalam tahun ini saja di Medan tercatat 3 pelajar dan 4 mahasiswa terpaksa ditahan, karena kedapatan memakai obat-obatan terlarang" (Waspada, 15 April 2013).

Berdasarkan hasil Survey Demografi Kesehatan Indonesia (SDKI, 2007) juga menunjukan jumlah masalah remaja di Indonesia yang bermasalah dengan kesehatan karena perilaku menyimpang mencapai $30 \%$ dari jumlah penduduk, jadi sekitar 1,2 juta jiwa. Beberapa masalah kesehatan karena perilaku menyimpang remaja diantaranya digambarkan sebagai berikut : 1). Seks pra nikah dan kehamilan yang tidak diinginkan, 2). Aborsi 2,4 juta dimana 700-800 ribu diantaranya adalah remaja, 3). Pernikahan usia remaja, 4). Komplikasi kehamilan dan persalinan, 5). HIV/AIDS: 1283 kasus, diperkirakan 52.000 terinfeksi dan $70 \%$ yang terinfeksi adalah remaja.

Indeks perilaku menyimpang remaja dalam bentuk penggunaan narkoba akhir-akhir ini semakin meningkat, ini dapat dilihat dari data di Direktorat Tindak Pidana Narkoba pada Maret 2012 yang menunjukkan 6.480 kasus $(32,64 \%)$ dilakukan oleh pelajar SMP dan 9.222 kasus $(46,46 \%)$ dilakukan oleh pelajar SMA. Remaja SMP dan SMA adalah yang terbanyak terlibat dalam kasus perilaku menyimpang dalam penggunaan narkoba dibanding pelajar SD dan Perguruan Tinggi. Angka ini meningkat dibandingkan dengan kasus yang sama pada tahun-tahun sebelumnya (Direktorat Tindak Pidana Narkoba, 2012).

Berdasarkan data-data dan fenomena yang dipaparkan diatas, masalah perilaku menyimpang remaja atau kenakalan remaja cukup mencengangkan, bagaimana mungkin anak remaja yang masih dalam pendidikan tingkat SMP dan SMA yang masih polos, energik, potensial yang menjadi harapan orang tua, masyarakat dan bangsa dapat terjerumus kedalam limbah kenistaan, sungguh sangat disayangkan. Tanpa disadari pada saat ini, diluar sana anak-anak remaja kita sedang terjerat dalam pengaruh narkoba, minuman keras, geng motor, tawuran, seks bebas, aborsi dan perilaku menyimpang atau kenakalan remaja lainnya. Bahkan angka-angka tersebut diprediksikan akan terus menanjak, seperti fenomena gunung es, tidak tampak di permukaan namun jika ditelusuri lebih dalam ternyata banyak ditemukan kasus-kasus yang cukup mengejutkan.

Untuk menghindari masalah penelitian yang cukup luas, maka penulis membatasi penelitian pada remaja berumur 13-16 tahun tentang bagaimana komunikasi keluarga sebagai strategi menangani perilaku menyimpang remaja di SMP Hikmatul Fadhillah Medan, dimana keluarga yang termasuk hanya pada keluarga inti. 
Secara khusus, penelitian ini bertujuan untuk menghasilkan indeks pengukuran kualitas komunikasi keluarga sebagai strategi menangani penyimpangan perilaku di kalangan remaja pada siswa SMP Hikmatul Fadhillah Medan.

Berdasarkan uraian yang telah dikemukakan, maka hipotesis yang diajukan untuk diuji dalam penelitian ini adalah :

H0 :tidak terdapat hubungan yang positif antara komunikasi keluarga dengan perilaku remaja

H1 : terdapat hubungan yang positif antara komunikasi keluarga dengan perilaku remaja. Ada hubungan yang positif antara komunikasi Keluarga dan perilaku remaja terhadap perilaku menyimpang. Semakin efektif komunikasi dalam keluarga, maka semakin rendah sikap remaja terhadap perilaku menyimpang.

\section{Proses Komunikasi}

Kata atau istilah komunikasi (dari bahasa Inggris "communication"), secara etimologis atau menurut asal katanya adalah dari bahasa Latin communicatus, dan perkataan ini bersumber pada kata communis Dalam kata communis ini memiliki makna 'berbagi' atau 'menjadi milik bersama' yaitu suatu usaha yang memiliki tujuan untuk kebersamaan atau kesamaan makna. Jika dua orang terlibat dalam komunikasi maka komunikasi akan terjadi atau berlangsung selama ada kesamaan makna mengenai apa yang dikomunikasikan. Komunikasi menyarankan bahwa suatu pikiran, suatu makna atau suatu pesan dianut secara sama (Mulyana, 2010:46)

Pengertian komunikasi secara efektif dalam Effendy (2011:10) bahwa para peminat komunikasi sering kali mengutip paradigma yang dikemukakan oleh Harold Lasswell dalam karyanya, The Structure and Function of Communication in Society. Lasswell mengatakan bahwa cara yang baik untuk untuk menjelaskan komunikasi ialah dengan menjawab pertanyaan sebagai berikut: Who Says What In Which Channel To Whom With What Effect? Effendy (2011: 11) membedakan proses komunikasi menjadi dua tahap, yaitu:

1. Proses komunikasi secara primer

Proses komunikasi secara primer adalah proses penyampaian pikiran dan atau perasaan seseorang kepada orang lain dengan menggunakan lambang (symbol) sebagai media. Lambang sebagai media primer dalam proses komunikasi adalah pesan verbal (bahasa), dan pesan nonverbal (kial/gesture, isyarat, gambar, warna, dan lain sebagainya) yang secara langsung dapat/mampu menerjemahkan pikiran dan atau perasaan komunikator kepada komunikan.

Seperti disinggung di muka, komunikasi berlangsung apabila terjadi kesamaan makna dalam pesan yang diterima oleh komunikan. Dengan kata lain, komunikasi adalah proses membuat pesan bagi komunikator dan komunikan. Pertama-tama komunikator menyandi (encode) pesan yang akan disampaikan disampaikan kepada komunikan. Ini berarti komunikator memformulasikan pikiran dan atau perasaannya ke dalam lambang (bahasa) yang diperkirakan akan dimengerti oleh komunikan. Kemudian giliran komunikan untuk menterjemahkan (decode) pesan dari komunikator itu. Ini berarti ia menafsirkan lambang yang mengandung pikiran dan atau perasaan komunikator tadi dalam konteks pengertiannya. Dalam proses itu penyandian komunikator berfungsi sebagai penyandi (encoder) dan komunikan sebaga pengawa-sandi (decoder).

2. Proses komunikasi sekunder

Proses komunikasi secara sekunder adalah proses penyampaian pesan oleh komunikator kepada komunikan dengan menggunakan alat atau sarana sebagai media 
kedua setelah memakai lambang sebagai media pertama. Seorang komunikator menggunakan media ke dua dalam menyampaikan komunikasike karena komunikan sebagai sasaran berada di tempat yang relatif jauh atau jumlahnya banyak. Surat, telepon, fax, surat kabar, majalah, radio, televisi, film, dsb adalah media kedua yang sering digunakan dalam komunikasi.

Devito (2011:54) menambahkan bahwa pesan non-verbal mempunyai ciri-ciri umum, yaitu :

1. Perilaku komunikasi bersifat komunikatif, yaitu dalam situasi interaksi, perilaku demikian selalu mengkomunikasikan sesuatu.

2. Komunikasi non-verbal terjadi dalam suatu konteks yang membantu menentukan makna dari setiap perilaku non-verbal.

3. Pesan non-verbal biasanya berbentuk paket, pesan-pesan non-verbal saling memperkuat, adakalanya pesan-pesan ini saling bertentangan.

4. Pesan non-verbal sangat di percaya, umumnya bila pesan verbal saling bertentangan, kita mempercayai pesan non-verbal.

5. Komunikasi non-verbal di kendalikan oleh aturan, komunikasi non-verbal seringkali bersifat metakomunikasi, pesan non-verbal seringkali berfungsi untuk mengkomentari pesan-pesan lain baik verbal maupun non-verbal.

Indeks

Kata indeks dari bahasa Inggris index berasal dari kata indicate yang berarti menunjukkan. Di dalam Kamus Besar Bahasa Indonesia (KBBI), Indeks adalah daftar akata atau istilan penting yang terdapat di buku (biasanya pada akhir bagian buku) tersusun menuru abjad dan memberikan informasi mengenai halaman, tempat kata atau istilah itu ditemukan. Sulistyo (2008: 34) mendefinisikan bahwa, indeks merupakan daftar istilah yang disusun secara alfabetis atau dalam bentuk lain (kata, konsep, formula, nomor dan sebagainya) yang menerangkan tentang dokumen-dokumen. Menurut Mustafa (2008: 35), indeks merupakan salah satu sarana penelusuran literatur yang memberikan petunjuk tentang karya tulis apa saja yang telah diterbitkan dalam berbagai majalah atau dokumen bentuk lain mengenai subjek tertentu, berisi informasi mengenai subjek karya tulis tersebut, pengarang, penyunting (kalau ada), judul, sumber (kalau berbentuk majalah) dan sebagainya.

\section{Keluarga}

Pengertian Keluarga menurut BKKBN (1999), "Keluarga adalah dua orang atau lebih yang di bentuk berdasarkan ikatan perkawinan yang sah, mampu memenuhi kebutuhan hidup spiritual dan materil yang layak, bertakwa kepada Tuhan, memiliki hubungan yang selaras dan seimbang antara anggota keluarga dan masyarakat serta lingkungannya.

Barbaret (2004) menyatakan bahwa hubungan yang erat antara orangtua dengan remaja dapat menjadi penghalang terhadap perilaku meyimpang remaja. Begitu juga penelitian yang dilakukan oleh Klien at Al (1997) yang mendapatkan bahwa komunikasi antara ibu dan anak adalah salah satu variabel yang mempunyai hubungan dengan peningkatan atau penurunan tingkat penyimpangan perilaku dikalangan remaja.

\section{Komunikasi Efektif}

Aspek-aspek efektivitas komunikasi antar pribadi yang diungkapkan oleh Devito di dalam Suranto (2011), yakni pertama keterbukaan (openness). Keterbukaan adalah sikap dapat menerima masukan dari orang lain, serta berkenan menyampaikan informasi penting kepada orang lain. Hal ini tidaklah berarti bahwa orang harus dengan segera membukakan 
semua riwayat hidupnya, tetapi rela membuka diri ketika orang lain menginginkan informasi yang diketahuinya. Sikap keterbukaan ditandai adanya kejujuran dalam merespon segala stimulasi komunikasi. Kedua, empati (empathy). Empati ialah kemampuan seseorang untuk merasakan seandainya menjadi orang yang diajak berkomunikasi, dapat memahami sesuatu yang sedang dialami orang lain, dapat merasakan apa yang dirasakan orang lain dan dapat memahami sesuatu persoalan dari sudut pandang orang lain melalui kacamata orang lain. Empati akan membuat seseorang lebih mampu menyesuaikan komunikasinya.

Ketiga, dukungan (supportivenness). Komunikasi antarpribadi yang efektif adalah hubungan dimana terdapat sikap mendukung, artinya masing-masing pihak yang berkomunikasi memiliki komitmen untuk mendukung terselenggaranya interaksi secara terbuka. Oleh karena itu respon yang relevan adalah respon yang bersifat spontan dan lugas. Dukungan ini lebih diharapkan dari orang terdekat yaitu keluarga. Kelima, rasa positif (positiveness). Sikap positif ditunjukkan dalam bentuk sikap dan perilaku. Seseorang harus memiliki perasaan positif terhadap dirinya, mendorong orang lain lebih aktif berpartisipasi dan menciptakan situasi komunikasi kondusif untuk interaksi yang efektif. Apabila seseorang berpikir positif tentang dirinya, maka akan berpikir positif juga terhadap orang lain, sebaliknya bila menolak diri sendiri, maka akan menolak orang lain. Bila seseorang memahami dan menerima perasaan-perasaannya, maka akan lebih menerima perasaan-perasaan sama yang ditunjukkan orang lain. Keenam, kesetaraan/kesamaan (equality). Kesetaraan ialah pengakuan bahwa kedua belah pihak memiliki kepentingan, kedua belah pihak sama-sama bernilai dan berharga serta saling memerlukan. Komunikasi antar pribadi akan lebih efektif bila suasananya setara, artinya harus ada pengakuan diam-diam bahwa kedua belah pihak (orangtua dan remaja) menghargai, berguna dan mempunyai sesuatu yang penting untuk disumbangkan. Kemampuan orangtua dalam melakukan komunikasi akan efektif jika orangtua dapat membaca dunia anaknya (selera, keinginan, hasrat, pikiran dan kebutuhan).

Perilaku adalah tindakan atau aktivitas dari manusia itu sendiri yang mempunyai bentangan yang sangat luas antara lain : berjalan, berbicara, menangis, tertawa, bekerja, kuliah, menulis, membaca, dan sebagainya. Dari uraian ini dapat disimpulkan bahwa yang dimaksud perilaku manusia adalah semua kegiatan atau aktivitas manusia, baik yang diamati langsung, maupun yang tidak dapat diamati oleh pihak luar (Notoatmodjo, 2003).

Perilaku remaja dinilai dari sisi positif (tersenyum benar-benar terhadap satu sama lain, memvalidasi ide-ide orang lain, membuat lelucon yang benar-benar ramah, dan mendengarkan orang lain) dan negatif (mengganggu orang lain, mengkritik ide-ide orang lain, dan muncul tidak tertarik pada apa yang dikatakan orang lain) dalam interaksi diadik. Indikator positif dan negatif dianggap secara terpisah seperti yang telah direkomendasikan oleh peneliti lain. sistem pengkodean standard ini telah menunjukkan validitas (Allen, Porter, \& McFarland, 2006; . Allen et al, 2007).

Ada beberapa pengertian tentang perilaku menyimpang (Juvenile Delinquency) atau kenakalan remaja. Menurut M. Gold dan J. Petronio, kenakalan remaja diartikan sebagai tindakan oleh seseorang yang belum dewasa yang sengaja melanggar hukum dan yang diketahui oleh anak itu sendiri bahwa, jika perbuatan itu sempat diketahui oleh petugas hukum ia bisa dikenai hukuman (Sarwono, 2001).

Menurut Horton dan Hunt (1996), ciri-ciri yang bisa diketahui dari perilaku menyimpang sebagai berikut: 
a. Suatu perbuatan disebut menyimpang bilamana perbuatan itu dinyatakan sebagai menyimpang.

b. Penyimpangan terjadi sebagai konsekuensi dari adanya peraturan dan penerapan sanksi yang dilakukan oleh orang lain terhadap si pelaku menyimpang.

c. Ada perilaku menyimpang yang bisa diterima dan ada yang ditolak.

d. Mayoritas remaja tidak sepenuhnya menaati peraturan sehingga ada bentuk penyimpangan yang relatif atau tersamar dan ada yang mutlak.

Berdasarkan hasil penelitian Jonaidi, Nanang dan Nurmanina (2013), ditemukan bentuk-bentuk perilaku menyimpang terjadi di SMA Pembangunan yaitu:

1. Berkelahi lingkungan sekolah

2. Berpakaian tidak rapi di sekolah.

3. Membolos dari kegiatan sekolah.

4. Membawa ke sekolah barang yang tidak ada hubungannya dengan kegiatan Sekolah.

5. Terlambat masuk sekolah.

6. Merokok saat mengenakan pakaian sekolah di dalam kelas.

7. Minum-minuman keras (Miras) di sekolah maupun di luar sekolah.

8. Mengkonsumsi obat destro di sekolah.

\section{Remaja}

9. Menghisap lem lingkungan sekolah.

Hurlock (1999) membagi masa remaja menjadi dua bagian yaitu masa remaja awal 13-16 tahun dan remaja akhir 17-18 tahun. Ketentuan peraturan perundang-undangan menentukan batas usia seseorang belum dewasa adalah dibawah 18 tahun, (UU tentang HAM, UU No. 3 tahun 1997 tentang Pengadilan Anak, UU No. 23 tahun 2002 tentang Perlindungan Anak).

Menurut WHO (2012) dan Pinem (2009), remaja adalah seseorang yang berusia 1019 tahun, sedangkan menurut Soetjiningsih (2004) remaja berusia 11-20 tahun yang dibagi menjadi 3 tahap remaja awal (11-13 tahun), remaja tengah (14-16 tahun), dan remaja akhir (17-20 tahun).

\section{Teori S-O-R}

Teori S-O-R (Stimulus Organisme Respon) mengemukakan bahwa tingkah laku sosial dapat dimengerti melalui suatu analisis dari stimulus yang diberikan dan mempengaruhi reaksi yang spesifik dan didukung oleh hukum maupun penghargaan sesuai



Gambar 2.1. Model Teori S-O-

dengan reaksi (Rakhmat, 2004: 59). Teori ini mendasarkan asumsi bahwa penyebab terjadinya perubahan perilaku tergantung kepada kualitas rangsang (stimulus) yang berkomunikasi dengan organisme, baik dalam bentuk verbal maupun non-verbal. Artinya kualitas dari sumber komunikasi (sources) misalnya kredibilitas, kepemimpinan, gaya berbicara, sikap dan perilaku penyampai pesan itu sendiri sangat menentukan keberhasilan perubahan perilaku seseorang, kelompok atau masyarakat. 


\section{Komunikasi Keluarga}

Komunikasi berasal dari bahasa Inggris “communication”, secara etimologis atau menurut asal katanya adalah dari bahasa Latin communicatus, berasal dari kata communis. Dalam kata communis ini memiliki makna 'berbagi' atau 'menjadi milik bersama' yaitu suatu usaha yang memiliki tujuan untuk kebersamaan atau kesamaan makna.

Komunikasi keluarga merupakan interaksi yang terjadi dalam lingkungan keluarga berupa penyampaian pesan baik verbal maupun non verbal sehingga memicu perilaku pada bagian-bagian dalam keluarga, dimana bagian tersebut dalam proses pencarian jati diri. Dalam hal ini remaja lah yang sangat cepat menilai komunikasi keluarga yang dialami, sehingga eksplorasi sangat cepat dilakukan di lingkungan baik dalam keluarga maupun di luar keluarga ditambah lagi penggunaan alat teknologi informasi dan komunikasi yang memerlukan perhatian khusus dalam pemanfaatannya.

\section{Kerangka Konsep}

\section{Variabel Independen}

Komunikasi Keluarga

1. Aspek komunikasi efektif

2. Komunikasi remaja dengan orangtua

3. Komunikai remaja dan saudara

\section{Variabel Dependen}

Perilaku Menyimpang Remaja

1. Berkelahi lingkungan sekolah

2. Berpakaian tidak rapi di sekolah.

3. Membolos dari kegiatan sekolah.

4. Membawa ke sekolah barang yang tidak ada hubungannya dengan kegiatan Sekolah.

5. Terlambat masuk sekolah.

6. Merokok saat mengenakan pakaian sekolah di dalam kelas.

7. Minum minuman keras (Miras) di sekolah maupun di luar sekolah.

8. Mengkonsumsi obat destro di sekolah.

9. Menghisap lem di lingkungan sekolah.

Gambar 2.2. Kerangka Konsep

\section{Metode}

Penelitian ini menggunakan metode kualitatif dan kuantitatif. Penelitian ini merupakan penelitian dengan pendekatan kuantitatif karena penelitian ini bersifat korelasional antara dua variabel (John, Zechmeister, \& Zechmeister 2006) yaitu untuk mengetahui hubungan yang positif antara komunikasi keluarga dan perilaku remaja. Teknik pengumpulan data melalui wawancara mendalam kepada pakar sebagai infromasi tentang kualitas komunikasi keluarga menggunakan pendekatan kualitatif diamana hasil wawancara digunakan sebagai tambahan dalam pembentukan instrument pertanyaan dalam 
kuesioner. Populasi diambil dari remaja berumur 13-16 tahun yang sedang mengikuti pendidikan di Sekolah Menengah Pertama (SMP) Hikmatul Fadhillah Medan yang akan dipilih menjadi responden penelitian. Daftar responden akan diperoleh langsung dari SMP Hikmatul Fadhillah Medan.

Menurut Bird, Gould, \& Staghezza (1992), We chose a self-report measure because of consensus that adolescents are the most valid reporters of their own internalizing problems. Kami memilih ukuran laporan diri karena konsensus bahwa remaja adalah wartawan yang paling valid dari masalah intern mereka. (Bird, Gould, \& Staghezza, 1992). Teknik pengumpulan data dalam penelitian ini menggunakan:

1. Wawancara (interview) langsung kepada pakar seperti ; Dosen, guru BP, Kepala Sekolah SMP Hikmatul Fadhillah Medan serta beberapa ahli yang dianggap berkompeten dalam penelitian ini.

2. Angket, yaitu dengan cara menyebarkan daftar pertanyaan berupa kuesioner, dimana dalam setiap pertanyaan tersedia empat alternatif jawaban.

3. Dokumentasi dilakukan dengan mengumpulkan dan mempelajari data-data pendukung berupa, struktur organisasi, daftar nama siswa serta perekaman kegiatan penelitian.

4. Studi literatur dilakukan dengan mengumpulkan dan mempelajari konsep, teori dan hasil penelitian yang berasal dari perpustakaan dan jurnal penelitian.

Uji t bertujuan untuk melihat pengaruh variabel bebas yaitu komunikasi keluarga sebagai strategi menangani perilaku menyimpang remaja pada siswa SMP Hikmatul Fadhillah. Menurut Sugiyono (2008:184), rumusannya sebagai berikut :

\section{Dimana :}

$$
\begin{array}{ll}
\mathrm{t} & =\text { nilai uji } \mathrm{t} \\
\mathrm{r}_{\mathrm{xy}} & =\text { nilai korelasi product moment } \\
\mathrm{n} & =\text { banyaknya sampel }
\end{array}
$$

\section{Hasil dan Pembahasan}

$$
t=\frac{r_{x y} \sqrt{n-2}}{\sqrt{1-\left(r_{x y}\right)^{2}}}
$$

Berdasarkan hasil jawaban kuesioner dapat disimpulkan bahwa pada SMP Hikmatul Fadhillah Medan terdapat perilaku menyimpang tetapi masih dalam kategori kecil, walaupun dalam jumlah kecil, perilaku menyimpang pada remaja memerlukan perhatian khusus dari pihak sekolah terutama dalam keluarga agar tidak semakin meningkat penyimpangannya dan penyebarannya kepada remaja yang lain.

Analisis data penelitian dilakukan secara kualitatif pada sumber data yang digunakan sebagai tambahan instrument pembentukan kuesioner yang akan digunakan untuk analisis secara kuantitatif diperoleh dari wawancara pada pakar atau ahli dalam bidang yang berhubungan dengan pada penelitian ini.

1. Komunikasi Keluarga (Variabel X)

Komunikasi keluarga adalah komunikasi yang berlangsung dalam lingkungan keluarga. Menurut Firman (2014) bahwa komunikasi keluarga adalah komunikasi yang berlangsung dalam lingkungan keluarga secara terus menerus agar dapat membentuk 
kedekatan antar anggota keluarga, seperti berbicara santun dan pemberian nasehat.

Kualitas komunikasi keluarga bukan seberapa lama seseorang berkomunikasi dalam keluarga, tetapi seberapa besar manfaat dan sisi edukasi yang terkandung dari komunikasi yang berlangsung (Sunaryo : 11-4-2014). Kualitas komunikasi keluarga dapat tercermin pada sikap dan tingkah laku keseharian, namun hanya sebagian kecil yang dapat lihat. Dalam keluarga, bukan hanya keharmonisan yang menjadi tolak ukur kualitas komunikasi keluarga, namunkonflik yang terjadi dan dialami anak khususnya remaja juga menjadi hal penting untuk meningkatkan kedewasaan, selama konflik yang terjadi masih dalam pengawasan orangtua dan dapat diselesaikan dengan cepat.

Konflik yang berkepanjangan juga dapat mempengaruhi kognitif remaja. Firman (13-4-2014) menambahkan :Konflkik dalam keluarga tidak dikatakan perlu, tetapi memang ada dan pasti terjadi. Karena dengan adanya konflik itulah kedua belah pihak antara kakak dan adik dapat instrospeksi diri, sehingga harus melibatkan orang tua untuk memberikan pengarahan dan wejangan agar tidak berkepanjangan. Orang tua juga akan mengerti akan permasalahan dan kebutuhann yang mendesak sehingga menimbulkan konflik.

\section{Perilaku Menyimpang Remaja (Variabel Y)}

Perilaku menyimpang remaja adalah perilaku dan sikap yang tidak seharusnya dilakukan remaja, apa lagi menjadi rutinitas. Perilaku dikatakan menyimpang apabila sudah tidak dalam batasan atau norma-norma yang berlaku dilingkungan sekitar dan norma-norma yang berlaku pada remaja khususnya. Ada beberapa perilaku menyimpang remaja terutama usia tingkat sekolah menengah pertama yang diperoleh dari hasil wawancara kepada para pakar dan ahli yang berhubungan dengan penelitian ini, di antaranya :

$\begin{array}{ll}- & \text { Pergaulan bebas } \\ - & \text { Tawuran } \\ - & \text { Merokok } \\ - & \text { Minum minuman keras } \\ \text { - } & \text { Menghisap Lem } \\ - & \text { Menonton film porno }\end{array}$

- Berkelahi

- Telat pulang kerumah

- Berpakaian tida rapi

- Tidak disiplin

- Membawa benda tajam kesekolah

Beberapa contoh perilaku menyimpang tersebut merupakan hasil pergaulan remaja dengan lingkungan, tidak semua remaja terjerumus pada pergaulan ini. Manusia merupakan makhluk sosial sehingga cara remaja berbaur dilingkungan tidak bisa sepenuhnya dipantau oleh orang tua, namun orangtua dapat meminimalisir tingkat penyimpangan perilaku dengan cara menanamkan nilai-nilai yang benar berupa suatu kebiasaan dan ditanamkan dengan sadar, tidak boleh ada pemaksaan tentunya melalui pemahaman agama kemudian komunikasi yang santun, komunikasi yang menyenangkan, silaturahmi saling menyayangi, waktu berssama, misal makan bersama, jalan-jalan serta menjelaskan sanksi dan efek dari hal yang dilakukan baik perilaku baik maupun menyimpang, seperti halnya yang diterapkan pada perusahaan dengan memberlakukannya reward and punishment.

Sentuhan fisik yang dilakukan seperti menepuk bahu sambil memberikan nasehat atau memberikan "tamparan kecil" dengan ekspresi non verbal dan tidak menyakitinya sesuai dengan aturan semata-mata bukan karena emosi. Cara ini dapat memperkecil kemungkinan terjadinya perilaku menyimpang yang dipicu lingkungan atau bahkan dari keluarga itu sendiri. 


\section{Simpulan}

Hasil penelitian teridentifikasi berdasarkan keterbukaan (openness) masih perlu ditingkatkan, karena komunikasi yang kurang terbuka akan membentuk perilaku anak untuk menghindar bahkan menjauh dari orangtua. Sebagian besar anak kadang-kadang menghindar jika orangtua sedang sibuk, hal ini menunjukan sikap empati (empathy) yang perlu lebih ditanamkan. Dukungan (supportivenness) orangtau terhadap anak sudah berjalan dapat terlihat dari hasil jawaban kuesioner yang lebih bnayak orangtua memberi izin akan hal-hal yang berprestasi. Rasa positif (positiveness) sangat erat dengan dukungan sehingga perlu kepada orangtua untuk berpartisipasi pada kegiatan yang dilakukan remaja. Saling menghargai dan menghormati baik terhadap yang lebih muda maupun yang lebih tua serta saling bercerita merupakan kesetaraan/kesamaan (equality) yang terjadi dalam komunikasi keluarga. Kualitas komunikasi keluarga yang berlangsung sudah baik, hal ini teridentifikasi berdasarkan hasil kuesioner yang telah dijawab.

Pada siswa SMP Hikmatul Fadhillah Medan terdapat perilaku menyimpang remaja, namum dalam jumlah dan persentase yang kecil. Komunikasi keluarga dengan perilaku menyimpang sangat berhubungan karena semakin baik komunikasi yang berlangsung maka semakin kecil kemungkinan terjadi perilaku menyimpang pada remaja. Pengaruh terhadap perilaku ini memperkuat teori S-O-R (Stimulus Organisme Respon) yang mengemukakan bahwa tingkah laku sosial dapat dimengerti melalui suatu analisis dari stimulus yang diberikan dan mempengaruhi reaksi yang spesifik dan didukung oleh hukum maupun penghargaan sesuai dengan reaksi (Rakhmat, 2004: 59).

\section{Referensi}

Abiyoso, Octo J., (2012). Hubungan Efektifm Komunikasi Antarpribadi dalam Keluarga dengan Motivasi Belajar Anak di Sekolah. eJurnal Mahasiswa Universitas Padjadjaran, Vol. 1., No.1.

Alias M, Fatmawati \& Mochtaria. (2013). Kontrol Sosial Tokoh Masyarakat (Ustad) dalam Mengatasi Penyimpangan Perilaki Remaja di Desa Limbung

Kecamatan Sungai Raya Kabupaten Kubu Raya. Jurnal tesis PMIS-UNTAN-PSS.

Allen, J. P., Porter, M., McFarland, F. C., McElhaney, K. B., Marsh, P. 2007. The relation of attachment security to adolescents' paternal and peer relationships, depression, and externalizing behavior. Child Dev. 2007 ; 78(4): 1222-1239.

Ardianto, Elvinaro. (2009). Public Relations Praktis. Bandung : Widya Pajajaran

Arikunto, Suharsimi. (2002). Metodologi Penelitian. Penerbit PT. Rineka Cipta. Jakarta.

Atmasasmita, Romli. (2005). Problema Kenakalan Anak-Anak dan Remaja, Bandung: Amico.

Azten, I. 2005. The Theory Of Planned Behaviour. Organizational behavior and human discussion processes, Open University Press. 50, 179-211.

, I. (2005). Attitudes, Personality and Behaviour. Second Edition. Open University Press.

Azwar, Azrul. 2002. Pengantar Epidemiologi. Jakarta Barat : Penerbit Binarupa Aksara. Edisi Revisi.

Barberet, R., Bowling B., Junger-Tas, J., Rechea-Alberola, C., Van Kasusteren, J. \& Zurawan, A. (2004). In self-report Juvenile Delinquency England and Wales, The 
Netherland and Spain. Publication Series No. 43, European Institute For Crime Prevention and Control.

Bobak. Lowdermilk. (2004). Buku Ajar Keperawatan Maternitas. Edisi keempat. Jakarta: EGC.

Bungin, Burhan. (2006). Sosiologi Komunikasi: Teori, Pradigma, dan Diskursus Teknologi Komunikasi di Masyarakat. Jakarta: Kencana Prenada Media Group.

Cangara, H. 2011. Pengantar Ilmu Komunikasi. Jakarta: Rajawali Pers.

Cheung, Y.W., (1997). Family, School, Peer, and Media Predictors of Adolescent Deviant Behavior in Hongkong. Jurnal Of Youth Adolescence, 26 (5), 569-595.

Clark, R.D. \& Shield, G., (1997). Family Comunication and Delinquency. Adolescence, 32 (125), 81-92.

Daryanto. (2011). Ilmu Komunikasi. Bandung: PT Sarana Tutorial Nurani Sejahtera.

Effendy, O. U. (2011). Ilmu Komunikasi “Teori dan Praktik”. Bandung: PT. Remaja Rosdakarya.

(2003). Ilmu, Teori dan Filsafat Komunikasi, Bandung : PT. Citra Aditya Bakti.

Gunawan, Hendri, (2013). Jenis Pola Komunikasi Orang Tua Dengan Anak Perokok Aktif Di Desa Jembayan Kecamatan Loa Kulu Kabupaten Kutai Kartanegara. eJournal Ilmu Komunikasi, 2013, 1 (3): 218-233.

Gunawati, R., Hartati, S., \& Listiara, A. (2006). Hubungan Antara Efektivitas Komunikasi Mahasiswa dan dosen Pembimbing Utama Skripsi Dengan Stres Dalam Menyusun Skripsi Pada Mahasiswa Program Studi Psikologi Fakultas Kedokteran Universitas Diponegoro. Jurnal Psikologi Universitas Diponegoro. Vol. 3, No. 2 : 93-115. 